\title{
Relationships Between Selected Human Resource Management Practices and Dairy Farm Performance
}

\author{
R. E. Stup ${ }^{\star 1}$ J. Hyde, $†$ and L. A. Holden* \\ *Department of Dairy and Animal Science, and \\ †Department of Agricultural Economics and Rural Sociology, Pennsylvania State University, University Park 16802
}

\begin{abstract}
The objectives were to identify relationships between human resource management (HRM) practices used by dairy farm businesses and the productivity and profitability of the dairies. Explanatory variables were the following practices: training, job descriptions, standard operating procedures, milk quality incentives, and the employment of Spanish-speaking employees. The dependent variables were return on assets, return on equity, rolling herd average, and somatic cell count. The effects of individual HRM practices were analyzed to test for means separation between groups that "used" and those that "did not use" HRM practices. The results did not support expectations that differences exist between the groups. However, a significant positive relationship was found between return on equity and the use of continued training (used $=10.61 \%$; did not use = $-62.38 \%$ ), and a significant negative relationship was found between the use of standard operating procedures for feeding and somatic cell count (used $=263,000$; did not use $=214,000$ ). Profitability and productivity did not seem to be major factors in producers' decisions to use or not use HRM practices.
\end{abstract}

Key words: human resource management, labor management, profitability, productivity

\section{INTRODUCTION}

Dairy farm expansion and the associated increase in numbers of employees cause major changes in the responsibilities of dairy managers. On small dairy farms most management and labor activities are carried out by just a few people or by one individual. As a farm expands, management responsibilities tend to concentrate with one or a few managers and additional people are hired to take on the majority of the daily production labor (Hadley et al., 2002).

As more employees are added, managers must find better ways to ensure that employees are performing

Received August 1, 2005.

Accepted October 24, 2005.

${ }^{1}$ Corresponding author: RichStup@psu.edu high quality work. The set of practices that managers use to ensure quality employee performance is known as human resource management (HRM). Everything that managers do to recruit, select, train, communicate with, evaluate, and terminate employees is included in HRM (Dessler, 2003). Human resource management includes practices that managers use to organize, structure, and monitor production processes so that employees can more fully understand the process and the impact of their work on results.

Previous research suggests that managers of dairy farms struggle with the transition to HRM. Bewley et al. (2001) suggested that Wisconsin dairy producers who expanded their operations had more difficulty and were less satisfied with HRM than with other aspects of farm management. The researchers attributed this to the managers' lack of training in HRM.

Little is known of the impact of HRM on dairy farm business performance, but data are available from firms in other industries. Becker and Gerhart (1996) proposed the concept that HRM (unlike other sources of competitive advantage such as technology, location, or economies of size) is a complex human system that other firms cannot easily replicate. If true, then HRM can result in sustainable competitive advantages for firms.

Extensive research was conducted on the effects of HRM practices on firm performance by surveying human resource managers about performance data using a large database of publicly held US firms with 100 or more employees. Huselid (1995) combined individual practices such as training or selection into sets that he called high-performance work practices and estimated that a one-standard-deviation increase in high-performance work practices resulted in a $\$ 27,044$ increase in sales and a $\$ 3,184$ increase in profits.

Relationships between firm-level performance and HRM are complex and not always positive. Another study with 293 US firms examined widely used technical HRM practices such as compensation, training, and selection of employees in contrast to less common strategic HRM practices such as teams and employee empowerment (Huselid et al., 1997). The dependent variables were measures of performance that could be derived from company financial statements and market 
valuations. Specifically, these measures were employee productivity, gross rate of return on assets, and Tobin's $q$, which is a standard market-based measure. They found no relationships with technical HRM, but did find statistically significant relationships among strategic HRM and employee productivity, gross rate of return on assets, and Tobin's $q$.

In the dairy industry, little research has been conducted to determine the relationship between HRM practices and productivity or profitability. However, production outcomes such as milk quality and quantity are, at least in part, a direct result of employee performance. Better understanding of the relationships between HRM and productivity and profitability in dairies is needed. The objective of this study was to identify relationships between HRM practices used by dairy farms and performance results, as indicated by financial and productivity measures.

\section{MATERIALS AND METHODS}

This analysis was conducted with a preexisting data set that had been collected for the purpose of developing a profile of successful dairy farm businesses. The sample was not random and was not representative of the Pennsylvania dairy industry. A description follows of how the data were collected for the original project.

Agribusiness representatives $(\mathrm{n}=250)$ were asked to nominate dairies with above-average management and potentially high levels of profitability to participate in a research survey. Agribusiness representatives were lenders, accountants, veterinarians, nutritionists, and consultants who had knowledge of the dairy industry and worked with the owners and managers regularly. No formal measure of profitability was used to prescreen the nominations. Nearly 100 dairies were nominated and duplications removed resulting in more than 63 dairies added to the project list. Additionally, all dairies that participated in the Business Planning Assistance Program were included in the project list ( $\mathrm{n}=29$; Hyde et al., 2003). Ninety-two dairies were initially contacted by phone and asked to participate, and 88 dairies agreed to provide information. One interviewer gathered preliminary data via a 15-min phone conversation with the primary business owner. Data gathered in this phone survey included general farm demographics and specific information related to business planning and participation in the Business Planning Assistance Program.

\section{On-Farm Data Collection}

Three detailed questionnaires were prepared that covered information for all aspects of the dairy farm business. Questionnaire 1 addressed demographics, crop production, youngstock, and milk production. Questionnaire 2 addressed human resource management, biosecurity, equipment inventory, milking and mastitis, reproduction, housing facilities, and feeding management. Questionnaire 3 addressed business management, risk management, information management, metabolic disease, dairy quality assurance, and included a leadership style assessment tool.

The entire survey took between 1 and $2 \mathrm{~h}$ to complete. All questions were asked in the same order each time. The interviewers recorded additional comments that producers had for any of the questions. The interviewers asked the questions only as they were written and did not interpret any information for the producers to prevent any bias.

\section{Explanatory Variables}

The explanatory variables used in this analysis were specific HRM practices that were or were not used by the businesses in the sample. The following is a brief explanation of each variable and how it was measured.

Milk Quality Incentives. Some farms use financial rewards, or incentives, to encourage specific employee behaviors. Milk quality incentives are commonly used to improve the performance of milking employees and are typically paid when a predetermined level of milk quality is attained. This variable was recorded as "use" or "do not use" a milk quality incentive.

Performance Reviews. Performance reviews are periodic interviews between employees and their supervisors to discuss performance. They are widely recognized as an important HRM tool for providing feedback to employees about their job performance. Ideally, this information can be used by employees to improve performance and will be used by employers as a basis for promotion and salary decisions. This variable was recorded as "use" or "do not use" performance reviews.

Spanish-Speaking Employees. In recent years, many dairy farms have hired employees who are originally from Mexico and other Spanish-speaking countries. In many cases, there are profound language and cultural differences between these employees and the local dairy owners and employees. These differences can interfere with normal business communications such as performance feedback and training. Dairy managers attempt to overcome these problems by hiring interpreters, using Spanish-language training materials, and other methods. Respondents indicated "yes" or "no" when asked if any of their employees' native languages was Spanish. No data were gathered about how many or what percentage of employees were native Spanish speakers. 
Standard Operating Procedures. Standard operating procedures (SOP) are written instructions used to manage variation that is introduced in production systems when individuals perform tasks in different ways. This variation can be quite detrimental; especially in production processes that directly influence herd performance such as milking, feeding, and reproductive tasks. The use of SOP for milking, feeding, and reproductive tasks was assessed. Respondents indicated "yes" or "no" when asked if they used each type of SOP.

Continuing Training. Producers were asked to indicate the approximate number of hours of training that employees receive per year, excluding new employees. This was designed to separate those farms that use training on a continuing basis for existing employees from those who do not. Respondents were grouped into those that "provided no continuing training" and those that "provided one or more hours of continuing training."

Job Descriptions. Finally, job descriptions are commonly used by business organizations to clarify the duties, roles, and specific responsibilities of employees. Ideally, job descriptions are used as a basis for performance appraisal and feedback and to improve communications about specific job responsibilities. Respondents were grouped into those where "at least some of the workforce had job descriptions" and those where "none of the workforce had job descriptions."

\section{Dependent Variables}

The effects of individual HRM practices were analyzed to identify differences in return on assets (ROA) and return on equity (ROE) between the group who "used" the HRM practices and the group that "did not." Return on assets $=[$ (net farm income $)+$ (interest $)-$ (unpaid management compensation)]/average total assets, and ROE = [(net farm income) - (unpaid management compensation)]/average equity assets. These measures represent the financial performance of the farms (Kay and Edwards, 1994). The ROA was chosen because it is a good indicator of efficiency of a business in making money with all assets (both debt and equity) it has available. The ROE is somewhat different from ROA because it measures the amount of money a farm generates in relation to the equity assets owned by the farm. Rolling herd average and SCC were used to represent productivity and milk quality, respectively.

Dairies that did not provide either complete financial or complete HRM data were removed from the data set. Additionally, 2 outlier observations were removed from the data set. One was removed because its ROE was extremely low. The other was removed because the owner equity value was large and negative, indicating an insolvent business. In both cases we felt that these observations did not represent viable businesses. The final data set for analyses contained data from 42 dairy farm businesses. All data were analyzed using the SAS package (SAS Institute, 2005). The GLM procedure was used to test for means separation by groups that "used" and those that "did not use" the HRM practices in the study. The GLM procedure allows us to perform an ANOVA on the variables of interest although the groups are of different sizes.

We tested the null hypothesis that the means of each of the 2 groups ("used" and "did not use") are equal. The test statistic is:

$$
F=\frac{\text { Sum of Squares (between) } / k-1}{\text { Sum of Squares (error) } / N-k}
$$

where sum of squares (between) is the sum of squared residuals between the 2 groups, sum of squares (error) is the sum of squared residuals within each group, $\mathrm{N}$ is the number of observations across both groups, and $\mathrm{k}$ is the number of groups (i.e., 2). This is an $F$ statistic distributed with $\mathrm{k}-1$ and $\mathrm{N}-\mathrm{k}$ degrees of freedom. Rejecting the null hypothesis indicates that the means are statistically significantly different. Where this is the case, we conclude that the HRM practice being analyzed has a significant influence on profitability, productivity, or milk quality.

\section{RESULTS}

Overall, the dairies had an average annual milk production per cow of $10,110 \mathrm{~kg}$ ( $\pm \mathrm{SD}=1,317)$, SCC of $261,000( \pm 98,000), \mathrm{ROA}$ of $7.14 \%( \pm 9.6)$, and ROE of $4.39 \%$ ( \pm 40.28; Table 1 ).

There were no significant differences in ROA, ROE (Table 2), rolling herd average, or SCC (Table 3) among farms due to the use of milk quality incentives, performance reviews, or job descriptions. Dairy businesses with one or more Spanish-speaking employees were not significantly different from those that did not use any Spanish-speaking employees in any of the measured variables.

The ROE for farms that used continuing training (10.6) was higher $(P=0.01)$ than for those that did not (-62.4; Table 2). The mean ROE for those farms that did not use training was quite low, but careful review of the data did not reveal reasons to exclude any observations other than the 2 mentioned previously. The use of continuing training did not make a significant difference for any other dependent variables. 
Table 1. Mean and standard deviation for human resource management practices used by dairy farm businesses, financial performance (return on assets, return on equity), and productivity (rolling herd average, SCC)

\begin{tabular}{llcc}
\hline Variable & $\mathrm{n}$ & Mean & SD \\
\hline Milk quality incentive & 29 & $0.24^{1}$ & - \\
Performance reviews & 41 & $0.32^{1}$ & - \\
Milking standard operating procedure (SOP) & 22 & $0.82^{1}$ & - \\
Feeding SOP & 22 & $0.64^{1}$ & - \\
Reproduction SOP & 22 & $0.27^{1}$ & - \\
Spanish-speaking employees & 41 & $0.29^{1}$ & - \\
Training & 40 & $0.88^{1}$ & - \\
Job descriptions & 40 & $0.50^{1}$ & - \\
Return on assets, $\%$ & 37 & 7.14 & 9.60 \\
Return on equity, $\%$ & 37 & 4.39 & 40.28 \\
Rolling herd average, kg/cow & 37 & 10,110 & 1317 \\
SCC, $\times 1000$ & 40 & 261.04 & 98.94 \\
\hline
\end{tabular}

${ }^{1}$ Coded for use of human resource management practices, $0=$ Do not use, $1=$ Use. Thus, the means presented here represent the proportion that used the practice.

Only one significant difference was found between those dairies that used SOP and those that did not (Table 3). Dairies using a feeding SOP had a higher $(P=0.03)$ SCC $(283,000)$ than those dairies that did not $(207,000)$.

\section{DISCUSSION}

One HRM practice, the use of continuing training, was associated with a difference in the ROE of dairy farms. This may indicate the potential for dairies to use continuing training to increase the efficiency of equity capital. Developing human capital through continuing training may increase the productive output from each employee either through improvement in skill level or through improvement in morale and job satisfaction (Dessler, 2003).

The significant, negative relationship between use of a feeding SOP and SCC was surprising and is likely an artifact of the small data set. We would not have been surprised to find a negative relationship between use of a milking SOP and SCC, because SOP are sometimes used to correct poor performance (Stup, 2001). Finally, the difference in mean ROA between those who use and do not use milk quality incentives was approaching significance. Milk quality incentives may help motivate employees to perform at a high level that leads to larger quantities of high-quality milk that can be sold. This would, of course, lead to an increase in the ROA of the business.

Most of the explanatory variables used in this analysis fall into the technical HRM category as defined by Huselid et al. (1997) and support the finding that technical HRM variables were not significant in explaining firm performance, whereas strategic HRM practices such as teams and employee participation were significant.

The data presented lead us to believe that profitability, milk quality, and milk quantity, as we measured, do not appear to be major reasons why managers use or do not use HRM practices, at least technical ones. Although these outcomes are certainly important to any

Table 2. Influence of use of human resource management (HRM) practices on dairy farm business financial performance as measured by return on assets (ROA) and return on equity $(\mathrm{ROE})^{1}$

\begin{tabular}{|c|c|c|c|c|c|c|c|c|}
\hline Practice & \multicolumn{4}{|c|}{$\mathrm{ROA}(\%)$} & \multicolumn{4}{|c|}{ ROE $(\%)$} \\
\hline Milk quality incentive & 26 & $14.45(17.79)$ & $6.74(7.66)$ & 0.13 & 26 & $16.1(44.06)$ & $0.72(49.25)$ & 0.49 \\
\hline Milking standard operating procedure (SOP) & 20 & $8.86(12.16)$ & $7.77(3.80)$ & 0.86 & 20 & $15.33(33.40)$ & $8.06(8.67)$ & 0.68 \\
\hline Feeding SOP & 20 & $8.33(13.36)$ & $9.11(6.53)$ & 0.88 & 20 & $12.94(36.49)$ & $15.28(18.74)$ & 0.87 \\
\hline Reproduction SOP & 20 & $5.81(4.42)$ & $9.86(12.71)$ & 0.46 & 20 & $16.98(35.28)$ & $6.61(10.02)$ & 0.49 \\
\hline
\end{tabular}

\footnotetext{
${ }^{1}$ Standard deviation in parentheses.

${ }^{2}$ The reported $P$-values represent the statistical significance of hypothesis tests for difference in means between those who indicated in a survey if they "use" or "do not use" a particular HRM practice.
} 
Table 3. Influence of use of human resource management practices on dairy farm business productivity as measured by rolling herd average (RHA) and somatic cell count (SCC) ${ }^{1}$

\begin{tabular}{|c|c|c|c|c|c|c|c|c|c|c|}
\hline & \multicolumn{5}{|c|}{ RHA (kg/cow) } & \multicolumn{5}{|c|}{$\mathrm{SCC}(\times 1000)$} \\
\hline & $\mathrm{n}$ & Use & & Do not use & $P^{2}$ & $\mathrm{n}$ & Use & & Do not use & $P^{2}$ \\
\hline Milk quality incentive & 25 & 10,075 & $(1,397)$ & $10,128(1,524)$ & 0.94 & 28 & 272 & (95.84) & $257(97.80)$ & 0.73 \\
\hline Performance reviews & 37 & 10,534 & $(1,111)$ & $9,908(1,380)$ & 0.17 & 40 & 292 & (103.95) & $246(94.88)$ & 0.18 \\
\hline Milking standard operating procedure (SOP) & 20 & 10,381 & $(1,313)$ & $10,772(883)$ & 0.63 & 21 & 263 & $(80.43)$ & $214(62.43)$ & 0.27 \\
\hline Feeding SOP & 20 & 10,198 & $(1,175)$ & $10,803(1,340)$ & 0.30 & 21 & 283 & (79.58) & $207(51.37)$ & 0.03 \\
\hline Reproduction SOP & 20 & 10,525 & $(632)$ & $10,412(1,411)$ & 0.87 & 21 & 264 & $(59.57)$ & $250 \quad(86.31)$ & 0.71 \\
\hline Spanish-speaking employees & 37 & 10,406 & $(1,034)$ & $9,980(1,420)$ & 0.38 & 40 & 238 & $(88.19)$ & $270(102.84)$ & 0.38 \\
\hline Training & 36 & 10,080 & $(1,385)$ & $10,541(474)$ & 0.59 & 39 & 254 & $(98.53)$ & $268(53.09)$ & 0.75 \\
\hline Job descriptions & 36 & 10,144 & $(1,260)$ & $10,089(1,454)$ & 0.94 & 39 & 268 & $(91.32)$ & $243(96.41)$ & 0.42 \\
\hline
\end{tabular}

${ }^{1}$ Standard deviation in parentheses.

${ }^{2}$ The reported $P$-values represent the statistical significance of hypothesis tests for difference in means between those who indicated in a survey if they "use" or "do not use" a particular HRM practice.

dairy farm business, there are likely other intermediate business outcomes that are more directly related to HRM practices such as employee turnover, employee job satisfaction, or owner satisfaction.

Future study of the effects of HRM practices on dairy farm productivity and profitability should be conducted with a random sample and a larger number of observations. Other farm characteristics that contribute to variation in productivity and profitability such as farm size and a recent history of major business changes such as expansion should be controlled (Ford and Shonkwiler, 1994). These other factors make it difficult to detect performance differences that HRM practices may contribute.

Because dairy farms are relatively small firms compared with the businesses studied in the HRM literature (Huselid, 1995; Becker and Gerhart, 1996; Huselid et al., 1997), it may be necessary to choose outcome variables that are more closely tied to HRM practices. For example, HRM practices are likely to have an impact on employee attitudes about work (Meyer and Allen, 1997), thus attitudinal factors such as job satisfaction or organizational commitment could be assessed. It may be helpful to use as explanatory variables some of the strategic HRM practices (Huselid et al., 1997), such as teams and employee participation, which were previously discussed. Finally, many HRM practices, such as training and performance incentives, are intended to influence employee behaviors (Dessler, 2003). Change in specific behaviors could be measured before and after a change in implementation to determine the effect of the HRM practices.

In conclusion, it appears from this study that technical HRM practices do not significantly affect dairy farm productivity and profitability. Further research is re- quired to determine the effects of strategic HRM practices.

\section{ACKNOWLEDGMENTS}

The authors wish to thank Nicole Fearnley and Michelle Jaymes-Parks for their dedicated work in collecting data for this project. We would also like to thank Ellie Hollabaugh for her work in reformatting the final version. The USDA provided partial support for this project.

\section{REFERENCES}

Becker, B., and B. Gerhart. 1996. The impact of human resource management on organizational performance: Progress and prospects. Acad. Manage. J. 39:779-801.

Bewley, J., R. W. Palmer, and D. B. Jackson-Smith. 2001. An overview of experiences of Wisconsin dairy farmers who modernized their operations. J. Dairy Sci. 84:717-729.

Dessler, G. 2003. Human Resource Management. Prentice Hall, Upper Saddle River, NJ.

Ford, S. A., and J. S. Shonkwiler. 1994. The effect of managerial ability on farm financial success. Agric. Resour. Econ. Rev. 23:150-157.

Hadley, G. L., S. B. Harsh, and C. A. Wolf. 2002. Managerial and financial implications of major dairy farm expansions in Michigan and Wisconsin. J. Dairy Sci. 85:2053-2064.

Huselid, M. A. 1995. The impact of human resource management practices on turnover, productivity, and corporate financial performance. Acad. Manage. J. 38:635-672.

Huselid, M. A., S. E. Jackson, and R. S. Schuler. 1997. Technical and strategic human resource management effectiveness as determinants of firm performance. Acad. Manage. J. 40:171-188.

Hyde, J., L. Holden, and A. Bair. 2003. Survey reveals consultants were well received. Hoard's Dairyman March 25:242.

Kay, R. D., and W. M. Edwards. 1994. Farm Management. McGrawHill, Inc., New York, NY.

Meyer, J. P., and N. J. Allen. 1997. Commitment in the workplace: Theory, research, and application. Sage Publications, Thousand Oaks, CA.

SAS Institute. 2005. SAS/STAT. Version 9.1. SAS Inst., Inc., Cary, NC.

Stup, R. E. 2001. Standard operating procedures: A writing guide. Penn State University Cooperative Extension, University Park. 